\title{
Breast Cancer in Countries of Limited Resources
}

\author{
Eva J. Kantelhardt ${ }^{\mathrm{a}} \quad$ Claudia Hanson $^{\mathrm{b}} \quad$ Ute-Susann Albert ${ }^{\mathrm{c}} \quad$ Jürgen Wacker $^{\mathrm{d}}$ \\ a Universitätsfrauenklinik der Martin-Luther-Universität Halle-Wittenberg, \\ ${ }^{b}$ Deutsche Gesellschaft für Technische Zusammenarbeit (GTZ), Eschborn, \\ ${ }^{\mathrm{c}}$ Frauenheilkunde und Geburtshilfe, Universitätsklinikum der Philips-Universität Marburg, \\ ${ }^{\mathrm{d}}$ Frauenklinik, Fürst-Stirum-Klinik Bruchsal, Germany
}

\section{Key Words}

Breast Cancer - Developing countries .

Global guidelines · Global Breast Health Initiative

\section{Summary}

For 2010, the annual incidence of breast cancer is estimated to increase from now 1.15 Mio to 1.5 Mio new cases per year. The increase is mainly seen in low and middle income countries. Resource limitations in means of finance, personnel, infrastructure, and by political instability are tremendous. Currently, little attention is paid to breast care in low-resource settings due to other health priorities. However, with increasing life expectancy and reduction of mortality due to infectious diseases, more people are confronted with non-communicable diseases, and the topic of cancer in developing countries will emerge more and more. Specific guidelines for breast cancer were given by the Global Breast Health Initiative differentiating according to available resources in different settings. From awareness in public and health care facilities to obtaining the diagnosis, deciding on strategies of treatment, and putting strategies into practice - all these obstacles differ substantially in developed and developing countries. Further research is essential to meet the challenge of breast cancer worldwide in the coming years.

\section{Introduction}

In developed and developing countries alike, breast cancer is the worldwide leading entity among cancers in women. It ac-

\author{
Schlüsselwörter \\ Brustkrebs · Entwicklungsländer, Globale Richtlinien . \\ Global Breast Health Initiative
}

\section{Zusammenfassung}

Im Jahr 2010 wird die jährliche Inzidenz des Mammakarzinoms weltweit von jetzt 1,15 Mio. auf 1,5 Mio. Neuerkrankungen pro Jahr ansteigen. Der Anstieg findet vor allem in Entwicklungsländern statt. Die Einschränkungen vorhandener Ressourcen sind in den Bereichen Finanzen, Personal und Infrastruktur sowie durch politische Instabilität enorm. Wegen grundlegenderer Probleme im Gesundheitsbereich wird dem Mammakarzinom in solchen Ländern bisher wenig Bedeutung beigemessen. Durch steigende Lebenserwartung und eine steigende Zahl von Patientinnen wird die Frage der Strategie im Umgang mit Krebserkrankungen in Entwicklungsländern in den Vordergrund rücken. Die Global Breast Health Initiative hat Leitlinien zum Mammakarzinom herausgegeben, die je nach vorhandenen Ressourcen unterteilt Empfehlungen zum Standard geben. Angefangen von der Aufklärung der Bevölkerung, über Diagnosestellung und Therapieoptionen bis hin zu Implementierung von Strategien - alle diese Hürden sehen in den Industrieländern sehr anders aus als in Entwicklungsländern. Mehr Forschung ist unentbehrlich, um den Herausforderungen des Mammakarzinoms weltweit in den nächsten Jahren gerecht zu werden.

counts for up to $10 \%$ of all diagnosed cancers, is the primary cause of cancer death in women, and is responsible for 375,000 deaths worldwide (2000). 55\% of all cases occur in developing countries [1]. The variation of incidence worldwide (fig. 1) is

\begin{tabular}{|c|c|c|}
\hline KARGER & (c) 2008 S. Karger GmbH, Freiburg & $\begin{array}{l}\text { Dr. med. Eva Kantelhardt } \\
\text { Universitätsfrauenklinik }\end{array}$ \\
\hline $\begin{array}{l}\text { Fax +49 } 7614520714 \\
\text { E-mail Information@Karger.de } \\
\text { www.karger.com }\end{array}$ & $\begin{array}{l}\text { Accessible online at: } \\
\text { www.karger.com/brc }\end{array}$ & $\begin{array}{l}\text { Ernst-Grube-Str. } 40 \\
06120 \text { Halle, Germany } \\
\text { Tel. +49 345557-1847, Fax -1501 } \\
\text { E-mail eva.kantelhardt@medizin.uni-halle.de }\end{array}$ \\
\hline
\end{tabular}


estimated to vary up to factor 10 . There are many speculations on why these differences occur. The suspected factors may be life expectancy, genetic, reproductive, hormonal, and nutritional factors as well as mammography screening.

The observation of migrants showed that environmental influence is high. The low-risk population from Asia migrating to the high-risk country USA will soon have descendants with high incidence in breast cancer. Although data is scarce, there is consensus about increasing incidence in developing countries when changes in lifestyle occur. Parkin [2] studied cancer registries from Latin America, Asia, and Africa comparing the 1960ies with the 1990ies. Latin America has intermediate rates, increasing by up to twice the amount in some areas such as Colombia. Asia is diverse, having low incidence areas like India or China (less than 50 per 100,000) that are increasing. The main reason is higher incidence in younger birth cohorts. Africa shows an increase of former low incidence in the northern part, southern parts do increase slowly, but rates are altered by the AIDS epidemic promoting, for example, cervical cancer or Kaposi's sarcoma [2].

Known risk factors, such as early age at menarche, low parity, higher age at first birth, late menopause, and less breast feeding, relate mostly to the level of the oestrogen milieu of a woman. A higher socio-economic background plays a major role in greater incidence but also leads to reduced mortality because of earlier presentation and better treatment options [3]. These patterns are changing in the developing world. Also, more aggressive types of oestrogen receptor (ER)-negative, early onset breast cancer are seen in developing countries and may also explain higher fatality rates [4]. In 2002, approximately 1.14 Mio cases of breast cancer were estimated worldwide, more than half of them in low income countries. Annual increases in incidence of $0.3-3 \%$ will lead to an estimated 1.4-1.5 Mio new cases diagnosed in 2010 [5].

\section{Case Report}

During her 3rd pregnancy, a 35-year-old patient resident in Addis Abeba/Ethiopia presented with a palpable mass in the right breast. Being a nurse, she consulted 3 doctors who all told her this is a physiological situation due to hormonal changes. After delivery, she again consulted a surgeon because the mass was increasing in size. Mammography was not available. A fine needle aspiration was done but was inconclusive. After a second consultation, again a specimen was taken which the patient brought to a reputable pathologist in town. The result was 'malignancy suspected on cytology'. Now being 4 weeks after normal delivery, she went to the University Hospital for surgery. Mastectomy was offered and done within $24 \mathrm{~h}$. The result was a pT2pN2a(5/6)MxG3 ductal carcinoma of the breast. What further options are there in Addis Abeba/Ethiopia? Tamoxifen could be ordered with difficulties from abroad. The only chemotherapy possible to be ordered from abroad is oral cyclophosphamide - given in some cases as metronomic therapy. The waiting period for radiotherapy at the only institution available is 1 year. The patient tried to find options in other African countries. By search on the internet and personal communication, sub-saharan English-speaking Africa seems to be equipped with possibilities for chemotherapy in Kenya or South Africa only. In

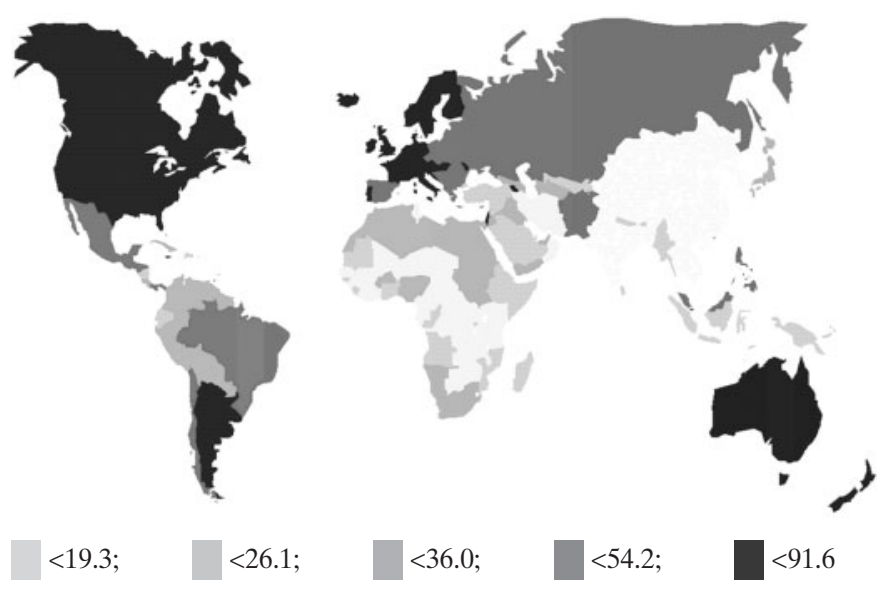

Fig. 1. Breast cancer incidence worldwide 2000 - age-standardised rates (world population) [10].

summer 2007, nearly the whole South African medical system was paralyzed by a general strike. Finding a possibility in Kenya without any known connection to a hospital or relatives in the country seemed nearly impossible.

Since the patient had a good relationship with the author with whom she had been working in a hospital in rural Ethiopia, she asked for advice. After some discussion at the Halle University Hospital, Germany, treatment was offered. After some struggle to obtain a visa, all papers were collected and the patient arrived 7 weeks after delivery. Additional immunohistochemistry and staging were done. The carcinoma was identified as hormone receptor-negative, and HER2 negative. According to current data [6], the given absolute benefit by chemotherapy is estimated as a nearly $40 \%$ progression-free survival after 10 years. The patient completed 3 cycles of $\mathrm{FEC}_{100}$ (fluorouracil, epirubicin, cyclophosphamide) and 3 cycles of docetaxel supported by granulocyte colony-stimulating factor. An axillary dissection was performed, no additional lymph node involvement was found. Standard radiotherapy was given. The patient returned from Halle to her family in January 2008.

The cost of the treatment was covered by means of the manpower of the clinic and donations for medication. This is, of course, an exceptional case, a rare development of chances, and an example which shows what can be achieved by joined efforts. But it is certainly not a solution for a constantly emerging problem worldwide. Most patients would probably have only noticed the mass, and watched it and waited. Some might have consulted doctors who might not have recognised the problem. If the diagnosis was confirmed histologically, some might have received surgery. The wealthier patients would have organised tamoxifen and maybe oral cyclophosphamide.

\section{What about Breast Cancer in Countries with Limited Resources?}

The Millennium Developmental Goals were declared in September 2000 at the United Nations Millennium Summit. World leaders agreed to set goals and targets for combating poverty, hunger, disease, illiteracy, environmental degradation, and discrimination against women. Time bound monitoring of these measurable goals is done - 2015 is the target year. Now is the half time assessment. Some good news are available [7]: 


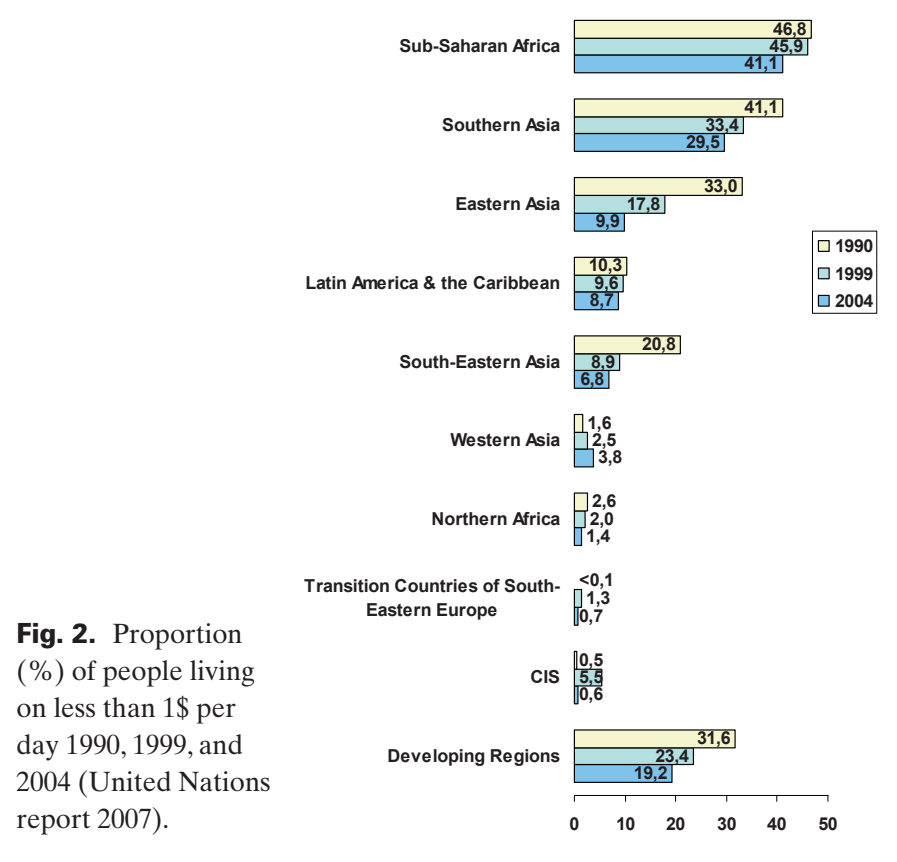

The proportion of people living in extreme poverty (fig. 2) fell from nearly one third in 1990 to less than one fifth in 2004. Primary education is available now for $88 \%$ of the children (2005) compared to $80 \%$ (1991). Women have achieved more political influence in parliaments. Child mortality has declined due to reduction of main killers like measles. Some decline in tuberculosis is seen. Still, the goals have not even been reached half way. Many deficiencies can be seen concerning employment, gender inequality, urbanisation problems, deforestation, water insecurity, and HIV prevalence. In general, a great number of interventions are hindered by conflicts, political instability, and insecurity. Key challenges are reduction of maternal mortality and underweight children, HIV/AIDS, sanitation, inequality of resource distribution within countries, and climate warming. Important factors for achieving the set goals and targets are committed national governments and sufficient financial resources. Although commitments have increased in the past years, many high income countries still lag behind in supporting the poorest countries in the world with an agreed share of $0.7 \%$ of the gross national income This unpredictable aid makes the implementation of continuous proposals difficult.

What is to be said about breast cancer in the setting of such obstacles? As gynaecologists and obstetricians, we are aware of the tragedy of a life-time risk of maternal death of 1 in 27 women in Ethiopia [8]. Can we discuss breast cancer cases there? Bearing in mind these tremendous basic problems throughout the world, we are certainly obliged to discuss it with a certain carefulness so as to not miss the target of improving women's health worldwide.

Seeing that poverty is indeed reduced slowly in many regions (fig. 1) means life expectancy is increasing.
Cancer is not the major problem in low income countries today, but numbers are increasing. For 2010, the annual incidence of breast cancer is estimated to increase from now 1.15 Mio to 1.5 Mio new cases per year. Many middle income countries in South-East Asia, Latin-America, and Northern Africa are now quickly undergoing a 'health transition' as they have successfully decreased the burden of communicable diseases. Non-communicable conditions like cardiovascular diseases and neoplasms are emerging as health priorities. The ratio of communicable to non-communicable diseases is $3.8 / 1$ in high mortality countries in Africa but $0.5 / 1$ in low mortality countries in South-East Asia $[9,10]$. Moreover, a small middle and upper class in the poorest countries are facing similar health needs like in the rich nations due to changing socio-demographic characteristics, life-style, and nutrition. Also, it is the patients in such countries who are slowly beginning to address the issue. Globalisation will accelerate interaction between the different worlds. Our patient from Ethiopia has a cousin in the United States with breast cancer who she knew had received chemotherapy. So naturally, she will start to search for it. There is an enormous amount of information on the internet. To avoid promotion of procedures and treatment with merely commercialised intentions, the scientific community has to communicate before other interests are driving the development - all the more looking at the enormous progress seen in developed countries concerning the battle against the disease. Key points are appropriate allocation of the scarce resources, adaptation of programs to the need of people and culture in the specific community, and realistic long-term considerations of manpower as well as political issues.

\section{Guidelines for Breast Cancer in Countries with Limited Resources}

In 2002, the Global Breast Health Initiative (GBHI; www. fhcrc.org/science/phs/bhgi/) was founded to improve breast health care and cancer treatment worldwide. There was a growing need for strategies that can be implemented in countries with limited resources according to their individual options. Since 2003, the GBHI has met every 2 years and agreed on guidelines that have been updated by methods of evidence based medicine and published. These recommendations are structured for 4 levels of resources to address the different circumstances: basic, limited, enhanced, and maximal. For each topic, the individual site can decide on which level the service should be implemented [11]. The following overview takes substantial parts of the guidelines into account.

\section{Women Getting Access to Care}

The clear goal of the detection of breast cancer is to find the earliest stages possible according to available resources. When 
Table 1. Resource allocation for Early Detection and Access to Care [20]

\begin{tabular}{lll}
\hline $\begin{array}{l}\text { Level of } \\
\text { resources }\end{array}$ & Detection method (s) & Evaluation goal \\
\hline Basic & $\begin{array}{l}\text { breast health awareness (education } \pm \text { self-examination); } \\
\text { clinical breast examination (clinical education) } \\
\text { targeted outreach/education encouraging clinical breast } \\
\text { Lexamination for at-risk groups } \\
\text { Limited }\end{array}$ & baseline assessment and repeated survey \\
Enhanced & $\begin{array}{l}\text { diagnostic mammography; opportunistic mammography } \\
\text { screening } \\
\text { population-based mammography screening; other imaging } \\
\text { technologies as appropriate: high-risk groups, unique } \\
\text { imaging challenges }\end{array}$ & $\begin{array}{l}\text { popportunistic screening of asymptomatic } \\
\text { patients } \\
\text { population-based screening of asymptomatic } \\
\text { patients }\end{array}$ \\
\hline
\end{tabular}

mammography is available, non-palpable lesions have a better prognosis than palpable lesions [12]. Within the palpable lesions, it is better to detect the smaller ones $[13,14]$. Reducing the size at first presentation gives better outcome as it has been shown in Ireland in the 1980ies, but most regions of the world do not have screening programs [15].

There are some more milestones before that. Women have to be empowered to seek health care as such. There has to be infrastructure for the diagnosis and treatment of breast cancer. This can only happen when education and awareness is promoted by local authorities. Higher sensitivity will be achieved when awareness and response to symptoms is carried out by as many of the population as possible having the opportunity to rely on attentive health professionals at all levels of care [16]. The most important message for awareness is that breast cancer is potentially curable when detected early. This is underlined when the public experiences cases of long-term survivors. Detecting a tumour in the breast can be done by clinical examination of the breast. Most investigations about the value of clinical examination are done in settings with mammography available. To date, no studies were published to examine its value without mammography as the gold standard. The situation is different when mammography is not available. There is a randomised controlled trial in the Philippines where 340,000 women were offered clinical breast examination by nurses. There was a good test sensitivity and improvement in stage at diagnosis. The major problem was that only $35 \%$ of the identified women with a tumour completed diagnostic follow-up because of fear of the diagnosis [17]. This stresses the urgent need of evaluating the specific situation, people, culture, and health facilities.

Training in breast self-examination (BSE) has not shown to reduce mortality in breast cancer [18]. Although BSE cannot be recommended on the basis of current evidence, it has a value in raising self-awareness for breast symptoms in women and might change behaviour. The outcome of any programme implemented (clinical breast examination or BSE) definitely has to be thoroughly evaluated measuring facts about the findings and impact on mortality and morbidity in the long term $[19,16]$.
Low income countries have a low incidence of breast cancer. Therefore, the efficacy of mammography screening programmes has to be questioned for methodological reasons. It has been shown that mammography screening reduces mortality when accompanied by quality assurance and audits of all participating health professionals [20]. All this additional effort has to be thoroughly considered before discussing mammography screening in resource poor countries [21]. Altogether, when mammography is not available, terms of breast examinations might be considered for implementation - if possible as programmes integrated in other running programmes like HIV, child health, maternal health care, or others. The Breast Health Global Initiative has given a strategy depending on the level of resources (table 1).

\section{Cultural Perspectives}

Many factors are known to influence people's behaviour towards health care. Major categories are culture, socio-economic status, and health experience. Especially when confronted with the possible diagnosis of cancer, fear, underestimation, fatalism, and pessimism are experienced by patients (studies among Afro-American patients) [22]. Some cultures do not have a word for cancer. There is fear of stigma to oneself or the family, fear of contagion or exclusion from the society. In many societies in Africa, patients prefer to first visit a traditional healer, and traditional explanations like witchcraft, bad air, or misbehaviour of the patient are still common. Patients think that knowledge of an incurable disease could lead to depression which might force them to commit suicide. Also, gender issues need to be considered, e.g. dependence on the husband and fear of a marriage break-up if the diagnosis is made. Altogether, it is of major importance to consider all these factors when trying to implement a strategy at any level of care. It is not a solution to blame the patients for their beliefs. Careful and appropriate design and implementation of breast cancer care is needed [23]. 
Table 2. Treatment and allocation of resources: stage I breast cancer

\begin{tabular}{|c|c|c|c|c|}
\hline \multirow{2}{*}{$\begin{array}{l}\text { Level of } \\
\text { resources }\end{array}$} & \multicolumn{2}{|l|}{ Loco-regional treatment } & \multicolumn{2}{|c|}{ Systemic treatment (adjuvant) } \\
\hline & Surgery & Radiation therapy & Chemotherapy & Endocrine therapy \\
\hline Basic & modified radical mastectomy & & & ovarian ablation; tamoxifen \\
\hline Limited & breast-conserving therapy ${ }^{a}$ & $\begin{array}{l}\text { breast-conserving } \\
\text { whole-breast irradiation } \\
\text { as part of breast- } \\
\text { conserving therapy } \\
\text { postmasectomy } \\
\text { irradiation of the chest } \\
\text { wall and regional nodes } \\
\text { for high-risk cases }\end{array}$ & $\mathrm{AC}, \mathrm{EC}$, or $\mathrm{FAC}^{\mathrm{b}}$ & \\
\hline Enhanced & & & taxanes & $\begin{array}{l}\text { aromatase inhibitors; } \\
\text { LH-RH agonists }\end{array}$ \\
\hline Maximal & $\begin{array}{l}\text { sentinel node biopsy; } \\
\text { reconstructive surgery }\end{array}$ & & $\begin{array}{l}\text { growth factors; dose } \\
\text { dense chemotherap }\end{array}$ & \\
\hline
\end{tabular}

$\mathrm{CMF}=$ Cyclophosphamide, methotrexane, 5 -fluorouracil; $\mathrm{AC}=$ doxorubicin, cyclophosphamide; $\mathrm{EC}=$ epirubicin, cyclophosphamide; FAC $=5$-fluorouracil, doxorubicin, cyclophosphamide; $\mathrm{LH}-\mathrm{RH}=$ luteinising hormone-releasing hormone.

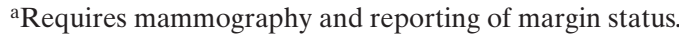

${ }^{b}$ Requires blood chemistry profile and complete blood count testing.

\section{The Challenge of Diagnostics}

The GBHI has set some standards for diagnostic procedures [24]: As with all other diseases, history and physical examination is standard. Special attention is given to the clinical examination of the breast. Staging for metastatic disease should be performed in patients with stage III disease whenever possible, since treatment may differ. In patients with small tumours stage I and II, it is unlikely to find metastasis by staging. Laboratory tests are not recommended in general. Introduction of diagnostic mammography needs to consider the following points: Are there equipment and personnel? Are the costs for the film covered? What size of lesion do patients present with? Which age group is addressed (young women have dense breasts)? Are there alternatives? Should it be used only when breast-conserving therapy can be offered? What about quality assurance?

Ultrasound is generally more available so that it can serve as a diagnostic tool in distinguishing cysts, evaluating whether a mass is suspicious, and it may guide tissue sampling. Also, the liver can be evaluated for metastasis by ultrasound. A problem will be that by clinical examination and ultrasound alone, many lesions may remain undetected. Needle biopsy or core biopsy has to be one of the first methods to be implemented. The correct microscopic evaluation of tissue specimen is the main essential step ahead. It should be guaranteed for all women to distinguish a malignant lesion from a benign finding. To provide such service, there are formal questions of organisation to be addressed like transport, labelling, archiving, documentation, and communication.

The minimally invasive biopsy is an optimal, less invasive, cheap diagnostic tool without the need for surgery (compared to surgical biopsy). The least invasive and least expensive is fine needle aspiration - but the specimens are sometimes small and difficult to interpret. The specimen could be sent to a central lab. Core needle biopsy gives more material for the pathologist but is more costly. In low resource settings, surgical biopsy might be the only option to give histological information. Still, a pathologist must be available. As a minimal standard, assessment of tumour size, histological type and grading should be performed. ER and progesterone receptor $(\mathrm{PgR})$ status need more financial options. The pathologist has to keep records and asses outcome to verify the accuracy of diagnosis. When few personnel are available, staff could be trained for different tasks that are needed, giving them in turn options to improve their status and income [24].

\section{Treatment Depending on Resources}

For the individual patient, a TNM classification should be done. Depending on resources, therapy should follow international guidelines (tables 2,3) [25]. Effective local treatment is the modified radical mastectomy. Breast-conserving therapy needs careful assessment, ultrasound and mammography should be available. Surgical margins have to be evaluated, and postoperative radiotherapy must be available. Certain patients may also need radiotherapy after modified radical mastectomy. Systemic treatment to prevent relapse is indicated according to the personal prognostic and predictive factors of the patient. Endocrine treatment with few side effects is recommended for hormone receptor-positive patients in countries with basic resources. Tumours should be considered hormone receptor-positive if the status is unknown. Ovarian abla- 
Table 3. Treatment and allocation of resources: stage II breast cancer

\begin{tabular}{|c|c|c|c|c|}
\hline \multirow{2}{*}{$\begin{array}{l}\text { Level of } \\
\text { resources }\end{array}$} & \multicolumn{2}{|l|}{ Loco-regional treatment } & \multicolumn{2}{|c|}{ Systemic treatment (adjuvant) } \\
\hline & Surgery & Radiation therapy & Chemotherapy & Endocrine therapy \\
\hline Basic & modified radical mastectomy & $-^{\mathrm{a}}$ & $\begin{array}{l}\text { classical } \mathrm{CMF}^{\mathrm{b}} \\
\mathrm{AC}, \mathrm{EC}, \text { or } \mathrm{FAC}^{\mathrm{b}}\end{array}$ & ovarian ablation; tamoxifen \\
\hline Limited & breast-conserving therapy ${ }^{c}$ & $\begin{array}{l}\text { breast-conserving } \\
\text { whole-breast irradiation } \\
\text { as part of breast- } \\
\text { conserving therapy } \\
\text { postmasectomy } \\
\text { irradiation of the chest } \\
\text { wall and regional nodes } \\
\text { for high-risk cases }\end{array}$ & & \\
\hline Enhanced & & & taxanes & $\begin{array}{l}\text { aromatase inhibitors; } \\
\text { LH-RH agonists }\end{array}$ \\
\hline Maximal & $\begin{array}{l}\text { sentinel node biopsy; } \\
\text { reconstructive surgery }\end{array}$ & & $\begin{array}{l}\text { growth factors; do } \\
\text { dense chemothera }\end{array}$ & \\
\hline \multicolumn{5}{|c|}{$\begin{array}{l}\mathrm{CMF}=\text { Cyclophosphamide, methotrexane, } 5 \text {-fluorouracil; } \mathrm{AC}=\text { doxoru } \\
\text { phamide; FAC = 5-fluorouracil, doxorubicin, cyclophosphamide; } \mathrm{LH}-\mathrm{R} \\
{ }^{\mathrm{a}} \text { Chest wall and regional lymph node irradiation substantially decrease } \\
\text { If available, it should be used as a basic-level resource. } \\
{ }^{\mathrm{b}} \text { Requires blood chemistry profile and complete blood count testing. } \\
{ }^{\mathrm{c}} \text { Requires mammography and reporting of margin status. }\end{array}$} \\
\hline
\end{tabular}

tion is an option in premenopausal women. Other options like aromatase inhibitors immediately raise costs, and side effects must be considered. If feasible, chemotherapy could be added. However, administration requires a skilled doctor. Depending on resources, CMF (cyclophosphamide, methotrexate, fluorouracil), anthracyclines, taxanes, and others should be given according to standards.

The same applies to locally advanced or metastatic breast cancer: operation will be widely available, and probably tamoxifen and/or ovarian ablation. Chemotherapy should be carefully considered taking the palliative situation into account. The balance between effect, side effects, safety, and costs must be maintained [26]. A national consensus has to be found on which patients should be given priority.

\section{Politics and Health Care System}

Prior to any intervention concerning breast cancer, a population-based cancer registry for cancer and cause of death should be made available [27]. In most countries it will be absent, so surrogate markers have to be found to measure the effect on outcome. Policy guidelines for treatment of cancer are given by the WHO [28]. The question is whether treatment of cancer will be available in the private sector for selected people or whether there are enough reasons to make it a national health care priority [29]. Health care professionals are accumulating in places with higher income - like bigger cities, financially strong neighbouring countries, or in developed countries. For countries with limited resources not only insufficient salaries, but also lack of career opportunities, lack of infrastructure, and awkward living conditions make it difficult to attract and keep professionals especially in remote areas where health care is needed. The number of nurses per habitant varies by factor 200 around the world [30]. Migration is a major problem - from rural to urban, from public to private, from poor to rich countries. The government could try to support centres of excellence according to the specific burden of breast cancer and the national resources for health, by having a Gynaecology Department where doctors are enabled to care for breast cancer. Necessary skills, instruments, a pathology department, and possibly radiology and chemotherapy should be available.

Implementing a new health care programme needs political will and a strategy. New structures can be developed or breast care can be integrated in existing programmes [31]. Cost-effectiveness is a major factor to be considered. So far, not many data are available about calculations in countries with limited resources. It is of the highest importance that resource allocation is done in a reasonable manner consistent with the setting and not for prestige or other reasons [32]. Governmental as well as non-governmental organisations are equally involved. Private-public partnership has been an emerging approach in recent years. An example of a non-governmental organisation is Famous Cancer Centre in Egypt, $140 \mathrm{~km}$ east of Cairo [33]. Noticing an increase in prevalence of breast and urinary bladder cancer, volunteers started a charity clinic in 1988. Today, $\mathrm{X}$-ray, ultrasound, mammography, image-guided biopsies, pathologic examination, endoscopies, surgery, radiotherapy, and chemotherapy are possible. In the past 15 years, almost 140,000 patients were seen and 20,000 of them admitted. 
There is a collaboration with Cairo University. Support is given by the WHO, occasional government grants, and US aid for research. Programs for public awareness are conducted, including door-to-door visits.

\section{Perspectives for Transnational Collaboration}

Breast cancer cases will continuously increase in number all over the world. The highest burden will be in countries with limited resources. Up to now, the WHO has proposed general guidelines for the treatment of cancer. The GBHI has given updated guidelines using current literature to give recommendations depending on levels of resources. The evaluation of first projects using the guidelines was presented at the last GBHI conference in October 2007; publication is anticipated next year.
More evidence-based research is needed, from basic epidemiology to efficacy of treatment in environments other then Europe or USA. This task must be put into the hands of the scientific community, and partnership between developed and developing countries is necessary. The local implementation is up to the government, the private sector, health care authorities, and stakeholders in public. A health care system must adapt to local resources and find out the most effective interventions for women affected by breast cancer. A good possibility is partnership between national societies of gynaecologists to prepare strategies. A partnership between the German Society of Obstetrics and Gynaecology (DGGG) and the Ethiopian Society of Obstetrics and Gynaecology (ESOG) has been established through the DGGG working group International Women's Health (AG FIDE: www.ag-fide.de). In that way, transnational projects can be carried out for research and treatment as steps to global improvement.

\section{References}

1 Bray F, McCarron P, Parkin DM: The changing global patterns of female breast cancer incidence and mortality. Breast Cancer Res 2004;6:229-239.

2 Parkin DM: Cancer in developing countries. Cancer Surv 1994;19/20:519-561.

3 Adams J, White M, Forman D: Are there socioeconomic gradients in stage and grade of breast cancer at diagnosis? Cross sectional analysis of UK cancer registry data. BMJ 2004;329:142.

4 Kamangar F, Dores GM, Anderson WF: Patterns of cancer incidence, mortality and prevalence across five continents: defining priorities to reduce cancer disparities in different geographic regions of the world. J Clin Oncol 2006;242137-2150.

5 Parkin DM, Bray F, Ferlay J, Pisani P: Clobal cancer statistics 2002. CA Cancer Clin 2005;55:74-108.

7 United Nations yearly report: www.united-nations. org.

8 World Health Organisation: Maternal Mortality in 2005. Estimates Developed by WHO, UNICF, UNFPA, and The World Bank. WHO, Geneva, 2007.

9 World Health Organisation: The World Health Report 2003. Shaping the Future. WHO, Geneva, 2003

10 Ferlay J, Bray F, Pisani P, Parkin DM: GLOBOCAN 2000: Cancer Incidence, Mortality and Prevalence Worldwide. IARC Cancer Base No. 5, Lyon, IARC Press, 2001

11 Anderson BO, Shyyan R, Eniu A, Smith RA, Yip $\mathrm{CH}$, Bese NS, Chow LWC, Masood S, Ramsay S, Carlson RW: Breast cancer in limited-resource countries: an overview of the Breast Health Global Initiative 2005 Guidelines. Breast J 2006;12(suppl 1):3-15.

12 Nystrom L, Andersson I, Bjurstam N, Frisell J, Nordenskjold B, Rutqvist LE: Long-term effects of mammography screening: updated overview of the Swedish randomised trials. Lancet 2002;359: 909-919.
13 Michaelson JS, Andersson I, Bjurstam N, Fristell J, Nordenskjold B, Rutqvist LE: Long-term effects of mammography screening: updated overview of the Swedish randomised trials. Lancet 2002;359: 909-919.

14 Elkin EB, Hudis C, Begg CB, Schrag D: The effect of changes in tumor size on breast carcinoma survival in the U.S.: 1975-1999. Cancer 2005;104: 472-475.

15 Pisani P, Forman D: Declining mortality from breast cancer in Yorkshire, 1983-1998: extent and causes. Br J Cancer 2004;90:652-656.

16 Smith AR, Caleffi M, Albert US, Chen THH, Duffy SW, Franceschi D, Nyström L: Breast cancer in limited-resource countries: early detection and access to care. Breast J 2006;12(suppl 1):16-26.

17 Pisani P, Parkin DM, Ngelangel C: Outcome of screening by clinical examination of the breast in a trial in the Philippines. Int J Cancer 2005;118: 149-154.

18 Thomas DB, Gao DL, Self SG, Allison CJ, Tao Y, Mahloch J, Ray R, Qin Q, Presley R, Porter P: Randomized trial of breast self-examination in Shanghai: final results. J Natl Cancer Inst 2002;94: 1445-1457.

19 Albert AS 2003: Breast cancer in limited-resource countries: early detection and access to care. Breast J;9(suppl 2):S90-S93.

20 Smith RA, Duffy SW, Gabe R, Tabar L, Yen AM, Chen TH: The randomized trials of breast cancer screening: what have we learned? Radiol Clin North Am 2004;42:793-806.

21 Duffy SW, Tabar L, Vitak B, Warwick J: Tumor size and breast cancer detection: what might be the effect of a less sensitive screening tool than mammography? Breast J 2006;12(suppl 1):91-95.

22 Lannin DR, Matthews HF, Mitchell J, Swanson MS: Impacting cultural attitudes in African-American women to decrease breast cancer mortality. Am J Surg 2002;184:418-423.

23 Dein S: Explanatory models of an attitudes towards cancer in different cultures. Lancet Oncol 2004;5: $119-124$.
24 Shyyan R, Masood S, Badwe RA, Errica KM, Liberman L, Ozmen V, Stalsberg OH, Vargas H, Vass L: Breast cancer in limited-resource countries: diagnosis and pathology. The Fred Hutchinson Cancer Research Center. Breast J 2006;12(suppl 1): 24-37.

25 Goldhirsch A, Wood WC, Gelber RD, Coates AS, Thurlimann B, Senn HJ: Meeting highlights: updated international expert consensus on the primary therapy of early breast cancer. J Clin Oncol 2003; 21:3357-3365.

26 Eniu A, Carlson RW, Aziz Z, Bines J, Hortobágyi GN, Bese NS, Love RR, Vikram B, Kurkure A, Anderson BO: Breast cancer in limited-resource countries: treatment and allocation of resources. The Fred Hutchinson Cancer Research Center. Breast J 2006;12(suppl 1):38-53.

27 European Commission: Evaluation and Monitoring of Screening Programmes. Luxembourg: European Commission, Europe Against Cancer Programme, 2000 .

28 World Health Organization: Executive Summery. National Cancer Control Programmes: Policies and Managerial Guidelines. Geneva, World Health Organization, 2002, i-xxiv.

29 World Health Organization: Cancer Prevention and Control. Provisional Agenda Item 13.12. 58th World Health Assembly, Geneva, May 16-25, 2005.

30 World Health Organisation: Global Health Atlas, 2004. www.who.int/globalatlas/DataQuery/default. asp.

31 Victoria CG, Hanson K, Bryce J, Vaughan JP: Achieving unicersal coverage with health interventions. Lancet 2004;364:1541-1548.

32 Anderson BO, Yip CH, Ramsey SD, Bengoa R, Braun S, Fitch M, Groot M, Sancho-Garnier H, Tsu VD: Breast cancer in limited-resource countries: health care systems and public policy. Breast J 2006; 12(suppl 1):54-69.

33 Omar S, Khaled H, Gaafar R, Zekry AR, Eissa S, el-Khatib O: Breast cancer in Egypt: a review of disease presentation and detection strategies. East Mediterr Health J 2003;9:448-463. 